\title{
Keberadaan Bank Syariah dalam Tata Hukum Nasional
}

\author{
Aristoni \\ Fakultas Syariah IAIN Kudus \\ toni_kurnia12@ymail.com
}

\begin{abstract}
The presence of Islamic banks operating on a profit sharing system is the beginning of the history of the growth of Islamic banks in Indonesia as an effort to meet the needs of the people who want banking products and services that are not interest-based, and are not speculative or not violating the principles of justice and togetherness. In addition, the birth of Islamic banks is also an opportunity for Muslims to use to relate calmly without hesitation because it is based on strong religious motivation in mobilizing public funds to finance economic development towards the welfare of many people. The existence of Islamic banks in the national legal system has a strong foothold after the enactment of Law Number 7 of 1992 concerning Banking which has substantially regulated banking business activities that have an operational basis for profit sharing. Provisions for profit sharing contained in these laws and regulations have been used as the legal basis for the operation of Islamic banks in Indonesia.
\end{abstract}

Keywords: Bank, Sharia, National Law Regulations

\begin{abstract}
Abstrak
Kehadiran bank syariah yang beroperasi pada sistem bagi hasil adalah awal dari sejarah pertumbuhan bank syariah di Indonesia sebagai upaya untuk memenuhi kebutuhan masyarakat yang menginginkan produk dan layanan perbankan yang tidak berbasis bunga, dan tidak spekulatif atau tidak melanggar prinsip-prinsip keadilan dan kebersamaan. Selain itu, kelahiran bank syariah juga merupakan kesempatan bagi umat Islam untuk menggunakan berhubungan dengan tenang tanpa ragu-ragu karena didasarkan pada motivasi agama yang kuat dalam memobilisasi dana publik untuk membiayai pembangunan ekonomi menuju kesejahteraan banyak orang. Keberadaan bank syariah dalam sistem hukum nasional memiliki pijakan yang kuat setelah diberlakukannya Undang-Undang Nomor 7 Tahun 1992 tentang Perbankan yang telah secara substansial mengatur kegiatan bisnis perbankan yang memiliki basis operasional untuk pembagian keuntungan. Ketentuan bagi hasil yang terkandung dalam undang-undang dan peraturan ini telah digunakan sebagai dasar hukum untuk pengoperasian bank syariah di Indonesia.
\end{abstract}

Kata kunci: Bank, Syariah, Tata Hukum Nasional

\section{PENDAHULUAN}

Perwujudan kegiatan perekonomian Islam sesungguhnya telah memberi pengaruh luas terhadap upaya peningkatan kehidupan perekonomian masyarakat, serta memberikan pemahaman Islami bagi para pelaku ekonomi untuk berupaya secara intensif mendirikan lembaga keuangan yang berbasis non ribawi dan terbuka (Zuhri, 1996: 155). Dengan 
perwujudan kegiatan perekonomian tersebut telah menunjukkan bahwa secara konseptual kelembagaan dan kegiatan usaha yang berbasis syariah dapat memenuhi tuntutan kehidupan masyarakat yang sesuai dengan fitrah kehidupan manusia, sebab penggunaan instrumen bunga telah menimbulkan masalah yang melekat bagi kehidupan ekonomi dikarenakan instrumen bunga secara alamiah telah mengakibatkan ketidakmampuan masyarakat dalam masalah ekonomi lainnya, bahkan disinyalir penggunaan instrumen bunga yang telah mengakar kuat dalam kehidupan ekonomi masyarakat modern, maka akan berpengaruh pada tatanan kehidupan lainnya, antara lain kehidupan sosial, politik dan bidang lainnya dalam suatu negara (Jundiani, 2009: 4).

Lebih jauh, dominasi penggunaan instrumen bunga dalam perkembangannya juga menyebabkan kondisi masyarakat miskin yang bergerak dalam kegiatan ekonomi riil sulit untuk mendapatkan dukungan keuangan dari bank, dengan kata lain prinsip kebersamaan tidak dapat diterapkan pada kalangan masyarakat miskin yang tidak memiliki modal ekonomi, sehingga kondisi yang demikian itu dapat mengikis fondasi kehidupan sosial dan memperlebar jurang pemisah antara yang miskin dan yang kaya dalam tatanan kehidupan bermasyarakat, serta menyebabkan ketidakstabilan ekonomi. Lahirnya bank-bank syariah dalam satu dekade terakhir merupakan wujud komitmen masyarakat untuk menerapkan prinsip syariah dalam mewujudkan kesetaraan, kejujuran, dan keadilan melalui sistem mudharabah dan musyarakah.

Secara nasional, perjalanan perkembangan bank-bank berdasarkan prinsip non ribawi pada gilirannya berpengaruh ke Indonesia. Masyarakat muslim Indonesia di era tahun 1970-an telah diliputi pengharapan untuk dapat melakukan transaksi yang berbasis syariah, sejak di beberapa negara lain yang mayoritas penduduknya beragama Islam telah mendirikan perbankan yang berbasis syariah. Sehubungan dengan dikeluarkannya kebijakan yang mendorong pendirian bank-bank baru, maka para pihak yang berkepentingan telah berusaha dalam upayanya pendirian bank yang bebas bunga, namun dasar hukum kegiatan operasionalnya belum ditemukan dalam aturan hukum yang berlaku. Pada awalnya, lembaga keuangan yang menjalankan kegiatan usaha yang berbasis mudharabah telah dilaksanakan oleh kalangan praktisi ekonmi yang concern dengan kajian ekonomi Islam.

Cikal bakal pengaturan kegiatan operasional bank-bank syariah berbasis non ribawi di Indonesia tentunya tidak lepas dari peran para ulama yang telah memiliki komitmen yang kuat untuk mewujudkan pendirian bank yang berbasisi non ribawi tersebut, yakni dengan diselenggarkannya lokakarya bunga bank dan perbankan oleh Majelis Ulama Indonesia (MUI) pada tanggal 18-20 Agustus 1990 di Bogor. Kemudian hasil lokarya tersebut ditindaklanjuti dalam Musyawarah 
Nasional IV Majelis Ulama Indonesia yang berlangsung di Jakarta pada tanggal 22-25 Agustus 1990 yang menghasilkan kesepakatan membentuk Kelompok Kerja yang disebut Tim Perbankan Majelis Ulama Indonesia. Berdasarkan rekomendasi dan lokakarya ulama tersebut, sekaligus di undangkannya Undang-Undang Nomor 7 Tahun 1992 tentang Perbankan sebagai pengganti Undang-Undang Nomor 14 Tahun 1967 tentang PokokPokok Perbankan, dimana dalam ketentuan Pasal 1 angka 12 yaitu diperbolehkannya kegiatan operasional perbankan yang berbasiskan bagi hasil, maka Tim Perbankan Majelis Ulama Indonesia semakin memantapkan langkah dalam mendirikan bank berbasis non ribawi di Indonesia. Lahirnya Undang-Undang Perbankan tersebut sekaligus dimaknai sebagai hukum positif, yakni hukum yang sekarang, yang sedang berlaku (ius constitutum) dimana secara yuridis sebagai dasar pijakan perbankan dalam menjalankan serangkaian aktivitas ekonomi yang berbasis syariah.

Pada tahun 1992 merupakan awal sejarah pertumbuhan Bank Syariah di Indonesia, yaitu lahirnya bank syariah pertama yakni PT. Bank Muamalat Indonesia Tbk, dimana Bank Mualamat Indonesia ini diharapkan dapat memenuhi kebutuhan masyarakat yang mengehendaki produk dan jasa perbankan yang tidak berbasis bunga, serta tidak merupakan kegiatan yang spekulatif maupun tidak melakukan pelanggaran terhadap prinsip keadilan dan kebersamaan dalam kegiatan usahanya. Pada awal berdirinya, keberadaan bank syariah belum mendapatkan perhatian yang optimal dalam tatanan industri perbankan nasional. Kemudian setelah Undang-Undang Nomor 7 Tahun 1992 diganti dengan Undang-Undang Nomor 10 Tahun 1998 yang mengatur secara rinci landasan hukum serta jenis-jenis usaha yang dapat dioperasikan dan dilaksanakan oleh bank syariah, maka bank syariah mulai menunjukkan perkembangannya. Undang-Undang ini kemudian disusul dengan diterbitkannya Surat Keputusan Direksi BI.PBI No.4/1/PBI/2002 tanggal 27 Maret 2002, dimana memberikan arahan bagi bank konvensional untuk membuka cabang syariah atau mengkonversikan diri menjadi bank syariah. Lahirnya landasan yuridis yang menerapka dual banking system tersebut telah menjadikan perbankan syariah pertumbuhannya semakin pesat.

\section{PEMBAHASAN}

Sejak diundangkannya Undang-Undang Nomor 7 Tahun 1992 tentang Perbankan, Peraturan Pemerintah Nomor 72 Tahun 1992 tentang Bank Berdasarkan Prinsip Bagi Hasil, Undang-Undang Nomor 10 Tahun 1998 tentang perubahan Undang-Undang Nomor 7 Tahun 1992 tentang Perbankan, kemudian diperkuat dengan melalui Undang-Undang Nomor 23 Tahun 1999 tentang Bank Indonesia, hingga diundangkannya Undang- 
Undang Nomor 21 Tahun 2008 tentang Perbankan Syariah, kiranya sudah sangat jelas menunjukkan bahwa sistem ekonomi syariah utamanya di dalam sistem perbankan di Indonesia telah memiliki legitimasi dan kepastian hukum secara yuridis formal (Antonio, 2001: viii).

Dalam perspektif ini mengandung pengertian bahwa pelembagaan prinsip syariah sesungguhnya merupakan suatu bentuk konkretisasi proses transformasi subsistem hukum Islam menjadi bagian yang utuh dalam sistem hukum positif nasional dan menjadi seperangkat aturan yang secara eksklusif mengatur sistem operasional kegiatan usaha perbankan, yang pada gilirannya memperkuat otoritas hukum Islam dalam operasional konsep dan sistem ekonomi syariah. Dengan perkataan lain, keberadaan dan otoritas hukum Islam telah mendapatkan regulasi secara yuridis formal dimana pemberlakuannya dalam tertib hukum kegiatan usaha bisnis perbankan dan bahkan dalam kegiatan usaha ekonomi (Saudi dan Candra, 2016: 423).

Penerapan prinsip syariah sebagai bentuk pengembangan dari prinsip bagi hasil berdasakan syariah, atau prinsip muamalah berdasarkan syariah di dalam operasinal kegiatan usaha perbankan pada pokoknya merupakan suatu landasan pola hubungan bank dengan nasabah dalam sistem operasional kegiatan usaha perbankan (Saudi dan Candra, 2016: 423). Kendati jika didasarkan pada pengaturan hukum perbankan sesuai Undang-Undang Nomor 7 Tahun 1992 tentang Perbankan, dan aturan pelaksananya yaitu Peraturan Pemerintah Nomor 72 Tahun 1992 tentang Bank Berdasarkan Prinsip Bagi Hasil belum sepenuhnya memadai karena hanya menyebutkannya sebagai sistem bagi hasil, akan tetapi ternyata perbankan syariah telah terbukti memiliki daya tahan terhadap badai krisis ekonomi dan moneter yang terjadi di Indonesia (Jundiani, 2009: 30).

Secara konstitusional, dasar hukum ekonomi syariah berpijak pada Pancasila sebagai dasar negara dan Undang-Undang Dasar Negara Republik Indonesia Tahun 1945 Pasal 29 ayat (1) yang berbunyi bahwa "Negara berdasarkan atas Ketuhanan Yang Maha Esa; dan ayat (2) negara menjamin kemerdekaan tiap-tiap penduduk untuk memeluk dan untuk beribadat menurut agamanya dan kepercayaannya itu". Adapun ketentuan hukum formal yang megatur pelaksanaan kegiatan ekonomi syariah di Indonesia yaitu segala ketentuan yang telah melalui proses positivisasi oleh negara. Dengan demikian, sumber hukum dasar tertulis sebagai sandaran ekonomi syariah paling utama dan pertama dalam sistem hukum Indonesia kontemporer adalah ketentuan Pasal 29 UndangUndang Dasar Negara Republik Indonesia Tahun 1945. Kemudian sandaran hukum tertulis paling utama dan pertama dalam konteks sistem hukum ekonomi saat ini, tentu saja ketentuan Undang-Undang Nomor 10 Tahun 1998 tentang perubahan Undang-Undang Nomor 7 Tahun 1992 
tentang Perbankan, dengan segala produk peraturan pelaksanaannya berupa Peraturan Pemerintah, Peraturan Bank Indonesia atau Keputusan Bank Indonesia, dan lain sebagainya. Sandaran sumber hukum tertulis berupa Peraturan Bank Indonesia atau Keputusan Bank Indonesia ini, selain didasarkan pada ketentuan langsung Undang-Undang Nomor 10 Tahun 1998, juga telah diperkuat oleh ketentuan Pasal 4 Ketetapan MPR No.III/MPR/2000.

Perbankan syariah sebagai salah satu sistem perbankan nasional memerlukan berbagai sarana pendukung agar dapat memberikan kontribusi yang maksimal bagi pengembangan ekonomi nasional. Tuntutan atas pengaturan perbankan syariah semakin meningkat dengan mempertimbangkan pertumbuhan dan volume usaha bank syariah yang begitu pesat. Salah satu sarana pendukung penting yaitu adanya pengaturan yang memadai dan sesuai dengan karakteristiknya. Terkait hal tersebut, maka pengaturan tersendiri bagi perbankan syariah merupakan hal yang mendesak dilakukan untuk menjamin terpenuhinya prinsip-prinsip syariah, prinsip kesehatan bank bagi bank syariah. Kemudian yang tidak kalah pentingnya adalah diharapkan dapat memobilisasi dana dari negara lain yang mensyaratkan pengaturan terhadap bank syariah dalam Undang-Undang tersendiri. Pengaturan tersebut telah dituangkan dalam Undang-Undang Nomor 21 Tahun 2008 tentang Perbankan Syariah. Pembentukan Undang-Undang Perbankan Syariah menjadi kebutuhan dan keniscayaan bagi perkembangan lembaga tersebut (Jundiani, 2009: 33).

Pengaturan perbankan syariah pada hakikatnya bertujuan menjamin kepastian hukum dan memberikan keyakinan kepada masyarakat dalam menggunakan produk dan jasa bank syariah. Adapun pengaturan perbankan syariah dalam Undang-Undang perbankan ini meliputi jenis usaha, ketentuan pelaksana syariah, kelayakan usaha, penyaluran dana, dan larangan bagi bank syariah maupun Unit Usaha Syariah (UUS) yang merupakan bagian dari bank umum konvensional. Sehubungan dengan upaya penyelesaian sengketa yang dapat terjadi pada perbankan syariah, maka dapat dilakukan melalui pengadilan pada lingkungan Peradilan Agama. Upaya lain dalam penyelesaian sengketa perbankan syariah yaitu melalui musyawarah, mediasi perbankan, arbitrase, atau melalui pengadilan di lingkungan peradilan umum sepanjang disepakati didalam akad oleh para pihak (Jundiani, 2009: 34).

Di Indonesia, pengembangan bank syariah dianggap masih mempunyai prospek yang tinggi, jika kendala jaringan dapat diatasi. Hal ini diyakini karena peluang yang besar dapat dilihat dari beberapa hal sebagai berikut : 
a. Pengembangan instrumen keuangan syariah yang diharapkan akan semakin menarik investor dan aatau palaku bisnis masuk dan membesarkan industri perbankan syariah tertentu;

b. Respons masyarakat yang antusias dalam melakukan aktivitas ekonomi dengan menggunakan prinsip-prinsip syariah;

c. Kecenderungan yang positif disektor non-keuangan atau ekonomi seperti sistem pendidikan, hukum, dan lain sebagainya yang menunjang pengembangan ekonomi syariah nasional;

d. Potensi investasi dari negara-negara timur tengah dalam industri perbankan syariah nasional.

Prospek pengembangan bank syariah sebagaimana keyakinan di atas, akan tetapi sebagian kalangan berpandapat bahwa perkembangan bank syariah dalam masa beberapa tahun sejak diterbitkannya UndangUndang Nomor 7 Tahun 1992 tentang Perbankan, hingga saat ini dinilai masih menunjukkan pertumbuhan yang belum maksimal, bila dibandingkan secara komprehensif dengan pertumbuhan bank konvensional, hal ini ditunjukkan dengan populasi bank syariah yang masih kecil. Banyak tantangan dan permasalahan yang dihadapi dalam pengembangan perbankan syariah utamanya berkaitan dengan pelaksanaan suatu sistem perankan yang baru. Beberapa masalah yang dihadapi ekonomi syariah dalam menyongsong prospek ke depan ekonomi syariah di Indonesia, yaitu diantaranya :

a. Pemahaman masyarakat yang belum tepat terhadap kegiatan operasional perbankan syariah, adanya perbedaan karakteristik produk bank konvensional dengan bank syariah telah menimbulkan adanya keengganan bagi pengguna jasa perbankan hal ini timbul karena hilangnya kesempatan mendapatkan penghasilan tetap berupa bunga bank, untuk itu secara umum perlu diinformasikan bahwa penempatan dana pada bank syariah akan mendapatkan keuntungan yang lebih rendah;

b. Peraturan perbankan yang berlaku belum sepenuhnya mengakomodasi operasional bank syariah;

c. Jaringan bank pejabat bank syariah yang belum luas,pengembangan ini adalah perlu untuk perluasan jangkauan pelayanan kepada masyarakat;

d. Sumber daya manusia yang memiliki keahlian dalam perbankan syariah masih tergolong sedikit, hal ini disebabkan sistem ini belum lama dikembangkan (Saudi dan Candra, 2016: 430-431).

Beberapa tantangan dan permasalahan di atas, setidaknya pemerintah Indonesia telah melakukan upaya untuk membangun kendali sistem perbankan yang sehat dalam mendukung program pemulihan dan pemberdayaan ekonomi nasional, selain restrukturisasi perbankan juga adalah pengembangan sistem perbankan yang bertujuan yaitu pertama, 
keperluan jasa perbankan bagi masyarakat yang tidak dapat menerima konsep bunga bank. Kedua, peluang pembiayaan bagi pengembangan usaha berdasarkan prinsip kemitraan. Ketiga, keperluan akan produk dan jasa perbankan unggulan (Antoni, 2001: 30).

Untuk merealisasikan tujuan tersebut di atas sebagaimana yang diorientasikan untuk meningkatkan kompetensi usaha yang sejajar dengan sistem perbankan konvensional yang dilakukan secara komprehensif, maka fokus utama strategi yang dapat dilakukan dalam pengembangan sistem perbankan syariah sebagai berikut:

a. Penyempurnaan ketentuan, maka upaya yang dilakukan ialah penyesuaian perangkat bank sentral, Undang-Undang Perbankan dan penyusunan perangkat ketentuan pendukung kegiatan operasional bank syariah. Dalam ketentuan Undang-Undang Nomor 10 Tahun 1998 tentang perubahan Undang-Undang Nomor 7 Tahun 1992 tentang Perbankan, telah ditetapkan pasal-pasal yang membuka peluang terhadap pengembangan yang lebih luas untuk bank syariah termasuk pengaturan seluruh kegiatan operasional bank syariah;

b. Pengembangan jaringan bank syariah, maka hal ini ditujukan untuk menyediakan akses yang lebih luas kepada masyarakat dalam mendapatkan pelayanan jasa bank syariah, pengembangan jaringan ini dilakukan dengan cara meningkatkan kualitas bank umum syariah dan bank perkreditan rakyat syariah yang telah beroperasi, perubahan kegiatan usaha bank konvensional yang memiliki kondisi usaha bank berdasarkan prinsip syariah, dan pembukaan pejabat cabang syariah bagi bank konvensional yang memiliki kondisi usaha bank berdasarkan prinsip syariah;

c. Pengembangan mata uang, hal ini bertujuan untuk membantu pengembangan pasar uang antar bank syariah; dan

d. Pelaksanaan sosialisasi perbankan syariah, upaya ini bertujuan untuk memberikan informasi yang lengkap dan benar mengenai kegiatan usaha perbankan syariah kepada masyarakat (Suadi, 2017: 327).

Dengan berlakunnya Undang-Undang Nomor 10 Tahun 1998 serta Undang-Undang Nomor 3 Tahun 2004 tentang Bank Indonesia, maka Bank Indonesia secara legitimasi memiliki landasan hukum yang kuat bagi pembangunan perbankan syariah di Indonesia. Berdasarkan kedua Undang-Undang tersebut, Bank Indonesia sebagai pengemban amanat dalam mengembangkan perbankan syariah telah mengeluarkan beberapa kebijakan untuk meningkatkan kinerja perbankan syariah termasuk melakukan sosialisasi produk jasa dan layanan perbankan syariah kepada masyarakat sesuai blue print 2002 dimana merupakan kerangka dasar pengembangan perbankan syariah di Indonesia, meskipun pengembangan perbankan syariah pada awalnya tidak didasarkan pada pengaturan hukum melalui Undang-Undang perbankan sendiri. 
Pengaturan kegiatan usaha perbankan syariah hanya didasarkan pada pasal tertentu sebagai bank yang berdasarkan bagi hasil (Biro Perbankan Syariah Bank Indonesia, 2001: 1).

Sebagai salah satu upaya untuk meningkatkan kemandirian perbankan syariah dalam perekonomian nasional ialah dengan mengembangkan sistem ekonomi berdasarkan nilai Islam (syariah), mengangkat prinsip-prinsipnya ke dalam sistem hukum nasional. Prinsip syariah berlandaskan pada nilai-nilai keadilan, kemanfaatan, keseimbangan, dan rahmatan lil 'alamain (keuniversalan). Pengaturan prinsip kegiatan usaha perbankan syariah tersebut telah dituangkan dalam Pasal 2 Undang-Undang Nomor 21 Tahun 2008, yaitu 1) perbankan syariah dalam melakukan usahannya berasaskan prinsip syariah; 2) demokrasi ekonomi; dan 3) prinsip kehati-hatian. Kegiatan usaha yang berasaskan prinsip syariah perspektif penjelasan Pasal 2 Undang-Undang Perbankan Syariah yaitu kegiatan usaha yang tidak mengandung unsur meliputi riba, maisir, gharar, haram, dan zalim (Jundiani, 2009: 65-66).

Kegiatan usaha perbankan syariah yang berasaskan pada demokrasi ekonomi perspektif penjelasan Pasal 2 Undang-Undang Perbankan Syariah adalah kegiatan ekonomi yang mengandung nilai keadilan, kebersamaan, pemerataan, dan kemanfaatan. Selanjutnya, kegiatan usaha perbankan syariah yang berasaskan pada prinsip kehatihatian dalam perspektif penjelasan Pasal 2 Undang-Undang Perbankan Syariah yaitu kegiatan usaha perbankan syariah yang didasarkan pada pedoman pengelolaan bank yang wajib dianut guna mewujudkan perbankan yang sehat, kuat, dan efisien sesuai dengan ketentuan Peraturan Perundang-Undangan.

\section{Regulasi Perbankan Syariah Menuju Paradigma Supremasi dan Keadilan Hukum}

Kerangka regulasi perbankan syariah merupakan sesuatu hal yang penting memberi lingkungan yang baik untuk pertumbuhan dan pengembangan industri serta stabilitas sektor keuangan secara menyeluruh. Hal ini sangat relevan untuk perbankan syariah dimana terdapat banyak beragam jenis investasi yang rumit dan harus mematuhi ketentuan syariah dan inovasi yang terus berlanjut beserta implikasi resiko yang terkandung didalamnya. Kerangka regulasi untuk perbankan syariah harus mengakomodir karakter dasar perbankan syariah dengan pada saat yang sama mengatur isu-isu yang umum bagi semua lembaga intermedia keangan seperti manajemen kontrak, kepailitan, jaminan dan pemulihan aset. Regulasi perbankan juga harus memberi definisi yang tegas tentang lembaga bank syariah sejalan dengan persyaratan perizinan, permodalan, cakupan aktivitas, dan hubungannya dengan otoritas regulator. Regulasi perbankan syariah juga harus mampu 
mengidentifikasi, menilai, dan mengelola risiko yang inheren di dalam aktivitas perbankan syariah (Wibisono, 2009: 107).

Upaya pemerintah dalam mengundangkan Undang-Undang Nomor 10 Tahun 1998 tentang perubahan Undang-Undang Nomor 7 Tahun 1992 tentang Perbankan dan Undang-Undang Nomor 3 Tahun 2004 tentang perubahan atas Undang-Undang Nomor 23 Tahun 1999 tentang Bank Indonesia, setidaknya sudah memenuhi tugas pemerintah dari aspek instrumental hukumnya (Jundiani, 2009: 50). Namun demikian hal ini bukan berarti peranan pemerintah sudah selesai, akan tetapi pemerintah masih mempunyai tugas lain dalam memberikan jawaban atas permasalahan keadilan dan kebutuhan hukum yang dihadapi oleh perbankan syariah, para pelaku bisnis syariah dan masyarakat di masa depan. Pemerintah tidak cukup hanya menonjolkan pengatuan hukum dari aspek instrumental hukumnya saja, namun harus dimunculkan juga fungsi ekspresif hukumnya, yaitu yang mengungkapkan pandangan hidup dan nilai-nilai budaya masyarakat yang sedang menjalankan kehidupannya.

Kehadiran Undang-Undang Perbankan Syariah di Indonesia sudah semestinya tidak hanya sebagai kekuatan akselerator bagi industri perbankan syariah yang sedang tumbuh cepat, melainkan juga sebagai kekuatan transformasi bagi industri perbankan nasional secara keseluruhan agar lebih berorientasi pada sektor riil dan pelaksanaan sesuai dengan prinsip syariah sehingga terdorong terwujudnya perekonomian dan sehat dan kuat bebas dari riba. Dengan diberlakukannya Undang-Undang Perbankan, maka legalitas hukum baik dari aspek kelembagaan dan kegiatan usaha bank syariah telah terakomodir dengan jelas menjadi landasan yuridis yang kuat bagi perbankan dan para pihak yang berkepentingan. Undang-Undang tersebut telah memberikan peluang semakin besar bagi perkembangan bank-bank syariah (Bank Indonesia, 2007: 9).

Keberadaan Undang-Undang Perbankan Syariah tentunya sangat diharapkan tidak hanya sekedar mempercepat perkembangan bank syariah sebagai alternatif, akan tetapi lebih dari itu menjadikan perbankan syariah sebagai solusi bagi perekonomian yang kuat dan dinamis. Untuk itu, dalam pengaturan hukum perbankan syariah yakni harus didasarkan pada paradigma supremasi hukum yang adil dan responsif. Pengaturan hukum demikian ini akan memberikan keadilan dan penyelesaian persoalan hukum bagi pengguna hukum di masa depan, karena aturan hukum yang dibuat telah merespon kebutuhan hukum masyarakan dalam menjalankan kehidupannya. Pengaturan hukum perbankan syariah yang memadai akan dapat meningkatkan kemampuan bank didalam menyediakan produk dan jasa layanan bank yang berkualitas. 
Peningkatan kemampuan bank dalam mengeluarkan produk dan layanan bank syariah akan berpengaruh pada pelayanan nasaba bank dan anggota masyarakat yang tertarik melakukan transaksi syariah. Produk dan jasa layanan bank syariah yang berkualitas dan sesuai dengan kebutuhan dan atau kepentingan masyarakat merupakan perwujudan dari konsep market driven dalam pengembangan perbankan syariah. Oleh karena itu, regulasi perbankan syariah sudah seharusnya memperhatikan beberapa aspek diantaranya, yaitu pertama, regulasi harus mampu mendukung kegiatan operasional perbankan syariah yang sehat dan sesuai dengan karakteristik operasionalnya. Kedua, regulasi harus mampu mendorong perkembangan bank syariah di masa depan. Regulasi harus mendukung terciptanya iklim yang kondusif untuk masuknya pemain baru, termasuk pemain asing dan bank-bank konvensional yang sudah memiliki jaringan operasional yang luas atau mendorong aliansi strategis antara bank bank dengan lembaga-lembaga keuangan lainnya guna mencapai skala ekonomis operasional. Ketiga, regulasi harus mampu memberi landasan dan menjawab katiadaan institusi-institusi pendukung yang diperlukan bagi industri perbankan syariah, Dewan Syariah Nasional, Badan Arbitrase Syariah Nasional, Autor Syariah, Lembaga Penjamin Simpanan dan Pembiayaan Syariah, Peradilan Agama, serta Pusat Informasi dan Data Keuangan Syariah. Adapun institusi pendukung yang lengkap, efektif dan efisien memiliki andil penting terutama dalam memastikan stabilitas dan pengembangan perbankan syariah secara keseluruhan (Wibisono, 2009: 108).

Pengaturan hukum perbankan syariah yang telah dibuat memang harus ditegakkan kebenaran hukumnya. Kebenaran hukum tidak hanya didasarkan pada kepastian hukum yang bersifat kaku, misalnya perjanjian pembiayaan yang dibakukan, akan tetapi bagaimana kebenaran hukum dari perjanjian tersebut itu juga mengakomodasikan nilai-nilai keadilan. Para pelaku bisnis syariah dalam menjalankan kegiatan ekonomi harus berpedoman bahwa jiwa hukum adalah keadilan. Hukum yang ditegakkan oleh para pelaku bisnis syariah tidak hanya untuk mendapatkan kepastiannya, akan tetapi juga harus dapat memberi rasa keadilan bagi para pihak (Jundiani, 2009: 51).

\section{Keberadaan Bank Syariah Dalam Tata Hukum Nasional}

Bank syariah adalah bank yang beroperasi dengan tidak mengandalkan pada bunga. Bank Islam atau bank tanpa bunga ialah lembaga keuangan syariah yang operasional dan produknya dikembangkan berdasarkan al-Qur'an dan al-Hadits. Dengan kata lain bahwa bank Islam merupakan lembaga keuangan yang usaha pokoknya memberikan pembiayaan dan jasa-jasa lainnya dalam lalu lintas 
pembayaran serta peredaran uang yang pengoperasiannya disesuaikan dengan prinsip syariat Islam (Muhammad, 2004: 38).

Berdasarkan Pasal 1 angka 7 Undang-Undang Nomor 21 Tahun 2008 tentang Perbankan Syariah, bank syariah adalah bank yang menjalankan kegiatan usahanya berdasarkan prinsip syariah dan menurut jenisnya terdiri atas bank umum syariah dan bank pembiayaan rakyat syariah. Kemudian Pasal 1 angka 1 Undang-Undang Nomor 21 Tahun 2008 tentang Perbankan Syariah, menyebutkan bahwa perbankan syariah adalah segala sesuatu yang menyangkut tentang bank syariah dan unit usaha syariah yang mencakup kelembagan, kegiatan usaha, serta tata cara dan proses dalam melaksanakan kegiatan usahanya. Hal tersebut menegaskan bahwa segala hal mengenai perbankan syariah baik yang menyangkat kelembagaan, kegiatan usaha, maupun prosesnya dilakukan berdasakan Undang-Undang yang baru (Aristoni, 2008: 106).

Sementara itu, yang dimaksud tata hukum nasional adalah tata hukum Indonesia yang merupakan tata hukum yang ditetapkan oleh pemerintah Indonesia. Tata hukum berasal dari kata dalam bahasa Belanda "recht orde", yaitu susunan hukum yang artinya memberikan tempat yang sebenarnya kepada hukum. Yang dimaksud dengan "memberikan tempat dengan yang sebenarnya" adalah menyusun dengan baik dan tertib aturan-aturan hukum dalam pergaulan hidup supaya ketentuan yang berlaku dengan mudah dapat diterima dan digunakan untuk menyelesaikan setiap peristiwa hukum yang terjadi. Tata atau susunan itu pelaksanaanya berlangsung salama ada pergaulan hidup manusia yang berkembang. Karenanya, dalam tata hukum ada aturan hukum yang berlaku pada saat tertentu di tempat tertentu yang disebut juga hukum positif atau ius constitutum. Dengan demikian dapat dimengerti bahwa tata hukum Indonesia merupakan hukum positif dimana terdapat aturan-aturan hukum tertentu yang pernah berlaku dan sudah diganti dengan aturan hukum baru yang sejenisnya dan berlaku sebagai hukum positif baru (Soebekti, 1984: 5)

Kehadiran bank syariah pada perkembangannya juga telah mendapat dukungan dalam sistem perbankan nasional yang dapat dilihat dari beberapa pengaturan perbankan, yaitu pertama, pada tahun 1990 diselenggarakannya lokakarya Majelis Ulama Indonesia (MUI) untuk mendirikan bank syariah. Kedua, pada tahun 1992 dikeluarkannya Undang-Undang Nomor 7 Tahun 1992 tentang Perbankan yang mengatur bunga dan bagi hasil (dual banking system). Ketiga, pada tahun 1998 dikeluarkannya Undang-Undang Nomor 10 Tahun 1998 yang mengatur bank beroperasi secara ganda (dual system bank). Keempat, pada tahun 1999 dikeluarkannya Undang-Undang Nomor 23 Tahun 1999 yang mengatur kebijakan moneter yang didasarkan prinsip syariah. Kelima, tahun 2001 dikeluarkannya peraturan Bank Indonesia yang mengatur 
kelembagaan dan kegiatan operasional berdasarkan prinsip syariah. Keenam, pada tahun 2008 dikeluarkannya Undang-Undang Nomor 21 Tahun 2008 yang mengatur tentang perbankan syariah (Jundiani, 2009: 27).

Secara umum, dikeluarkannya regulasi perbankan syariah telah didukung oleh legislasi dan regulasi yang telah dikeluarkan sampai tahun 1999, yaitu Undang-Undang Perbankan dan Undang-Undang Bank 1997 telah muncul krisis ekonomi dan moneter di kawasan Asia termasuk Indonesia. Suatu keadaan yang menunjukkan bahwa pembangunan ekonomi yang berbasiskan pada bunga telah diterapkan tak terkecuali dibidang perbankan, moneter yang sedang terjadi. Sistem perbankan yang berbasis bunga dalam kegiatan yang bersifat spekulatif telah menyebabkan tumbuh dan berkembangnya moral hazard dalam transaksi ekonomi dapat berpengaruh terhadap runtuhya bangunan perekonomian bangsa Indonesia.

Menurut Mulya E Seregar, menyatakan bahwa wujud kegagalan lembaga keuangan yang berbasis bunga dalam menjalankan fungsinya yang berakibat terjadinya krisis kuangan Asia yaitu kualitas lembagalembaga keuangan yang dipengaruhi oleh penerapan suku bunga yang ternyata gagal berfungsi sebagai alat inderect screening mechanism. Manajemen moneter yang bertumpu pada suku bunga akan menghasilkan kegagalan pemenuhan pokok masyarakat bawah, kelompok kaya semakn kaya dan yang miskin akan semakin miskin, pertumbuhan ekonomi yang melambat dan ketidakstabilan perekonomian nasional. Dengan penerapan manajemen moneter melalui suku bunga, dua fenomena utama terjadi ialah tingginya tingkat inflasi dan tidak stabilnya nilai tukar (Seregar, 1999: 119).

Sejak berdirinya Bank Muamalat Indonesia sampai waktu krisis moneter tahun 1997, kegiatan perbankan syariah masih belum mendapat pengaturan hukum yang optimal dalam sistem hukum perbankan nasional. Pengaturan hukum perbankan syariah dalam sistem hukum perbankan nasional. Pengaturan hukum berbasis nilai dan penormaan syariah Islam yang pada akhirnya dituangkan dalam Undang-Undang Nomor 7 Tahun 1992 tentang Perbankan. Sebagai dasar hukumnya terkait teknis operasional dalam usaha perbankan dimana diatur dalam Peraturan Pemerintah Nomor 72 Tahun 1992 tentang Bank Berdasarkan Prinsip Bagi Hasil.

Terhadap para pihak-pihak yang berkepentingan utamanya dalam aktivitas perbankan berbasis non bunga, mengupayakan berjalannya sistem perbankan syariah di Indonesia berdasarkan Undang-Undang perbankan dan pelaksanaanya kendati perbankan hukum yang belum memadai dikarenakan hanya menyebutkannya sebagai sistem bagi hasil, ternyata perbankan syariah telah terbukti memiliki daya tahan terhadap 
krisis ekonomi dan moneter yang perah terjadi di Indonesia. Daya tahan perbankan syariah mampu menghadapi krisis ekonomi dan moneter pada tahun 1997 disebabkan keunggulan dalam penerapan prinsip dasar kegiatan operasional perbankan syariah kegiatan yang meliputi bunga, transaksi yang bersifat tidak transparan, dan spekulatif. Tentunya kelebihan ini dapat dijadikan sebagai alasan masyarakat luas perbankan syariah untuk mengembangkan perbankan yang berdasarkan syariah Islam, karena merupakan kebutuhan dasar untuk dikembangkan dalam dunia perbankan syariah (Jundiani, 2009: 29-30).

Perbankan syariah dapat dikatakan sebagai salah sistem perbankan nasional memerlukan berbagai sarana pendukung agar dapat memberikan kontribusi yang maksimal bagi pengembangan ekonomi nasional, sebab Undang-Undang Perbankan Syariah yang berlaku saat itu dalam perkembangannya kurang mengakomodir karakteristik operasional perbankan syariah. Tuntutan atas pengaturan perbankan syariah semakin meningkat dengan mempertimbangkan pertumbuhan dan volume kegiatan usaha bank syariah yang begitu pesat. Salah satu sarana yang cukup penting ialah adanya pengaturan yang memadai dan sesuai dengan karakteristiknya. Alasan inilah diperlukan pengaturan tersendiri bagi perbankan syariah merupakan hal yang mendesak dilakukan untuk menjamin terpenuhinya prinsip-prinsip syariah, prinsip kesehatan bank bagi bank syariah dan yang lebih penting adalah pengaturan yang dapat memobilisasi dari negara lain yang mensyaratkan pengaturan terhadap bank syariah dalam Undang-Undang tersendiri. Dan pengaturan tersebut tertuang dalam Undang-Undang Nomor 21 Tahun 2008 tentang Perbankan Syariah.

Pembentukan perbankan syariah bertujuan pada dasarnya menjamin kepastian hukum bagi stakeholders dan memberikan keyakinan kepada masyarakat dalam menggunakan produk dan jasa bank syariah. Pengaturan perbankan syariah dalam Undang-Undang Perbankan Syariah diantaranya meliputi jenis usaha, aturan pelaksanaan syariah, penyaluran dana, kelayakan usaha, dan larangan bagi Bank Syariah maupun Unit Usaha Syariah yang merupakan bagian dari bank umum konvensional. Selanjutnya, terkait pengaturan masalah kepatuhan syariah compliance dalam perspektif Undang-Undang Perbankan Syariah telah menjadikan kewenangan Majelis Ulama Indonesia yang akan dijalankan oleh Dewan Pengawas Syariah. Adapun tehadap pembentukan kepengurusan Dewan Pengawas Syariah harus dilakukan pada masing-masing bank syariah dan Unit Usaha Syariah. Sementara itu, Dewan Pengawas Syariah berpedoman pada peratuan Bank Indonesia. Ketentuan-ketentuan dalam peraturan Bank Indonesia tersebut berdasar pada fatwa yang telah dikeluarkan oleh Majelis Ulama Indonesia. 
Pada dasarnya kegiatan bank syariah tidak jauh berbeda dengan kegiatan bank-bank yang telah ada, hanya saja perbedaannya terletak pada orientasi konsep juga terletak pada konsep dasar operasionalnya sesuai dengan nilai-nilai ajaran Islam yang berdasarkan al-Qur;an dan alHadist, sedangkan bank konvensioanal konsep dan operasionalnya berbasis bunga. Dalam konteks di Indonesia, beroperasinya bank syariah harus disesuaikan dengan situasi dan kondisi masyarakat dan negara Indonesia, baik aspek sosial, ekonomi maupun aspek hukum. Selain itu juga harus memenuhi persyaratan pendirian dan operasionalnya sesuai dengan Peraturan Perundang-Undangan yang berlaku (Husain dan Suanto, 2003; 117).

\section{KESIMPULAN}

Berdasarkan uraian dalam pembahasan di atas, dapat disimpulkan bahwa keberadaan bank syariah dalam tata hukum nasional utamanya berkaitan dengan kegiatan operasionalnya didasarkan pada beberapa Peraturan Perundang-Undangan yang berlaku di Indonesia diantaranya, yaitu Undang-Undang Nomor 10 Tahun 1998 tentang perubahan UndangUndang Nomor 7 Tahun 1992 tentang Perbankan dan Undang-Undang Nomor 3 Tahun 2004 tentang perubahan atas Undang-Undang Nomor 23 Tahun 1999 tentang Bank Indonesia, Undang-Undang Nomor 21 Tahun 2008 tentang perbankan syariah. Lebih jauh keberadaan bank syariah di Indonesia secara formal dimulai sejak tahun 1992 dengan berlakunya Undang-Undang Nomor 7 Tahun 1992 tentang Perbankan yang ditandai dengan didirikannya Bank Muamalat Indonesia dan Bank Perkreditan Rakyat Syariah, meskipun penerapan ketentuan hukum perbankan yang kegiatan usahanya dengan prinsip bagi hasil tersebut belum mampu mendukung pergerakan perbankan syariah secara optimal dalam sistem hukum perbankan nasional. Namun demikian realita tersebut, perbankan yang kegiatan operasionalnya dengan menggunakan prinsip bagi hasil telah menunjukkan prestasi atas kemampuannya secara mandiri dimana mampu melewati badai krisis ekonomi dan moneter yang terjadi tahun 1997 karena keunggulan penerapan prinsip dasar kegiatan operasional perbankan syariah yang melarang kegiatan meliputi bunga (riba), transaksi yang bersifat tidak terbuka (gharar), dan spekulatif (maisir).

\section{DAFTAR PUSTAKA}

Antonio, Syafi. Bank Syariah Dari Teori Ke Praktik, Jakarta: Insani, 2001. Aristoni, Problematika Peran Perbankan Syariah Dalam Regulasi Kelembagaan Pengelolaan Zakat, Ziswaf: Jurnal Zakat dan Wakaf, Vol.5, No.1, Juni 2018. 
Biro Perbankan Syariah Bank Indonesia, Cetak Biru Pengembangan Perbankan Syariah di Indoonesia, Jakarta: Biro Perbankan Syariah Bank Indonesia, 2001.

Candra, Mardi dan Suadi, Arman. Politik Hukum Perspektif Hukum Perdata dan Pidana Islam Serta Ekonomi Syariah, Jakarta: Prenadamedia Group, 2016.

Husain dan Suanto, Menggagas Konsep Ekonomi Syariah : Jalan Menuju Tatanan Perekonomian yang Berkeadilan, Makasar: Umitoha Ukhuwah Grafika, 2003.

Muhammad, Manajemen Dana Bank Syariah, Yogyakarta:Ekonisia, 2004.

Suadi, Arman. Penyelesaian Sengketa Ekonomi Syariah : Teori dan Praktik, Jakarta: Kencana, 2017.

Soebekti, Pengantar Hukum Indonesia, Jakarta: Raja Grafindo Persada, 1984.

Wibison, Yusuf. Politik Ekonomi UU Perbankan Syariah Peluang dan Tantangan Regulasi Industri Perbankan Syariah, Bisnis dan Birokrasi, Jurnal Ilmu Administrasi dan Organisasi, Volume 16, Nomor 2, Mei-Agustus 2009.

Zuhri, Muh. Riba dalam al-Qur'an dan masalah Perbankan (Sebuah Tilikan Antisipatif), Jakarta: Raja Grafindo Persada, 1996. 
Halaman ini sengaja di kosongkan 